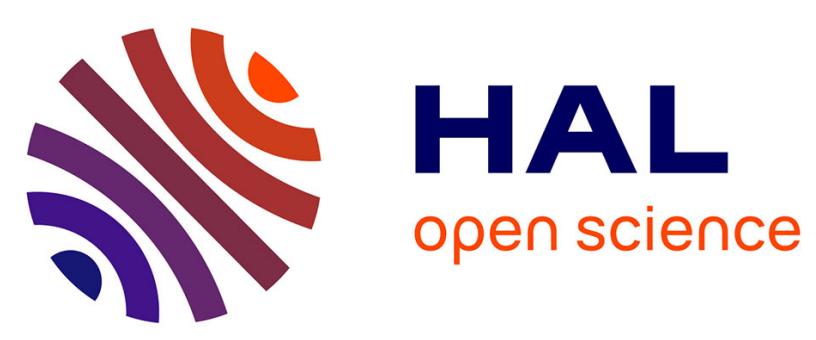

\title{
Selective hydrogenation of 1,5,9-cyclododecatriene in up- and down-flow fixed-bed reactors: experimental observations and modeling
}

Carine Julcour-Lebigue, Rengaswamy Jaganathan, Raghunath Vitthal Chaudhari, Anne-Marie Wilhelm, Henri Delmas

\section{To cite this version:}

Carine Julcour-Lebigue, Rengaswamy Jaganathan, Raghunath Vitthal Chaudhari, Anne-Marie Wilhelm, Henri Delmas. Selective hydrogenation of 1,5,9-cyclododecatriene in up- and down-flow fixedbed reactors: experimental observations and modeling. Chemical Engineering Science, 2001, vol. 56, pp. 557-564. 10.1016/S0009-2509(00)00260-8 . hal-00735867

\section{HAL Id: hal-00735867 https://hal.science/hal-00735867}

Submitted on 27 Sep 2012

HAL is a multi-disciplinary open access archive for the deposit and dissemination of scientific research documents, whether they are published or not. The documents may come from teaching and research institutions in France or abroad, or from public or private research centers.
L'archive ouverte pluridisciplinaire HAL, est destinée au dépôt et à la diffusion de documents scientifiques de niveau recherche, publiés ou non, émanant des établissements d'enseignement et de recherche français ou étrangers, des laboratoires publics ou privés. 


\title{
Selective hydrogenation of 1,5,9-cyclododecatriene in up-flow and down-flow fixed bed reactors: experimental observations and modeling
}

\author{
C. Julcour ${ }^{\dagger}$, R. Jaganathan ${ }^{\ddagger}$, R.V. Chaudhari ${ }^{\ddagger}$, A.M. Wilhelm ${ }^{\dagger}$, H. Delmas ${ }^{\dagger *}$. \\ ${ }^{\dagger}$ Laboratoire de Génie Chimique UMR - CNRS 5503 \\ ENSIGC, 18 Chemin de la Loge - 31078 TOULOUSE CEDEX 4, FRANCE \\ *National Chemical Laboratory - 411008 PUNE, INDIA \\ * corresponding author
}

\begin{abstract}
Performance of trickle and flooded bed reactors has been investigated and compared for an exothermic multistep catalytic reaction. Selective hydrogenation of cyclododecatriene over $\mathrm{Pd} / \mathrm{Al}_{2} \mathrm{O}_{3}$ has been studied in both up-flow and down-flow modes of operation in the same pilot reactor. In the down-flow mode, hot spots and runaway could not be avoided without diluting both catalyst bed and liquid reactant. With this diluted system, the up-flow reactor leads to a higher productivity and a much better selectivity. A non-isothermal plug flow reactor model predicts the performances of the up-flow reactor satisfactorily, but is found to be unsuitable to the case of a trickle bed reactor. In the later case, the productivity was underestimated when complete wetting of catalyst particles was assumed. On the other hand, when partial wetting effect was incorporated, the calculated selectivity was always much higher than observed actually in a trickle bed, due to heterogeneities of liquid velocity and partial wetting (poorly irrigated zones).
\end{abstract}

\section{KEYWORDS}

Up-flow, down-flow, flooded-bed, trickle-bed, modeling, selective hydrogenation.

\section{INTRODUCTION}

For many years fixed bed reactors with co-current down-flow of gas and liquid (Trickle-Bed Reactors) have been extensively studied and widely used in industrial practice, while less attention has been given to the up-flow mode (Flooded-Bed Reactors), which has advantages from the point of view of liquid flow distribution and thermal stability. In some of the recent work, the performance of both reactors has been compared for a wide range of operating conditions.

MILLS et al. (1984) examined the productivity of packed beds with down-flow, up-flow and countercurrent flow of gas and liquid for a gas-limited reaction using the hydrogenation of $\alpha$-methylstyrene in hexane as a model reaction. They observed similar conversion for co-current down-flow and countercurrent modes in the low interaction regime, while the co-current up-flow generally yielded lower values.

GOTO et al. (1984 and 1993) studied the oxidation of ethanol and the hydration of an olefin at atmospheric pressure in the down-flow and up-flow modes. They concluded that the trickle-bed is the most efficient reactor at lower gas and liquid velocities, because of the partial catalyst wetting leading to enhanced mass transfer rates of the gaseous reactant. KHADILKAR et al. (1996) compared both reactors over a wide range of operating pressures (from 30 to 200 psig), using the hydrogenation of $\alpha$-methylstyrene as a test reaction. They related the observed performance to the type of reaction system and limiting reactant phase (gas-limited or liquid-limited). When the reaction is gas-limited, at lower pressure and higher liquid feed concentration, trickle-bed reactor outperforms the up-flow reactor due to the ready access of the gas to the pores through incompletely (externally) wetted catalyst. At high pressure and lower liquid feed concentration, the reaction becomes liquid-limited and up-flow reactor performs better.

VERGEL (1993) investigated the selective hydrogenation of butadiene in a $\mathrm{C}_{4}$ olefinic cut in trickle-bed and up-flow reactors of $5.5 \mathrm{~cm}$ diameter. The selectivity was found to be constant in the flooded-bed over a wide range of fluid velocities, but decreased in the trickle-bed at lower liquid velocities. This selectivity decrease was explained by segregation phenomena inside the down-flow reactor in which flow heterogeneities encompassing several particles were detected by means of a coloured tracer.

Except this last study, all the previous work involved simple reaction schemes under isothermal conditions and little attention was paid to the influence of the hydrodynamic behaviour on the performance and thermal stability of a reaction with constraints of exothermicity and/or selectivity.

The aim of this paper is to compare the performance of fixed bed gas-liquid-solid reactors in two operation modes - up-flow and down-flow - for an exothermic multi-step catalytic reaction in the same pilot reactor. The selective hydrogenation of 1,5,9-cyclododecatriene (CDT) to cyclododecene on a shell type $\mathrm{Pd} / \mathrm{Al}_{2} \mathrm{O}_{3}$ catalyst 
represents an industrially important example of a multistep reaction and was used to investigate the reactor performance behavior. The principal products of the consecutive reactions are : cyclododecadiene (CDD), cyclododecene (CDE), and cyclododecane (CDA) respectively. A simplified reaction scheme considering lumping of isomers may be written as follows:

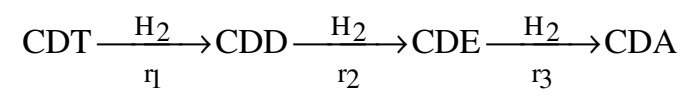

The comparison of the reactor performances in two modes has been studied by calculation of both the productivity and CDE selectivity, and heat transfer efficiency using theoretical models as well as by experimental observations at different operating conditions.

\section{EXPERIMENTAL}

\section{EXPERIMENTAL SET-UP}

The schematic of experimental setup of the fixed bed gas-liquid-solid reactor used is presented in Fig. 1. The reactor unit consists of a jacketed packed bed column with an inner diameter of $0.026 \mathrm{~m}$ and a bed height of $1.2 \mathrm{~m}$. The column is filled with cylindrical alumina pellets of $3.1 \mathrm{~mm}$ diameter coated with palladium to a depth of $250 \mu \mathrm{m}$ (Degussa, E263/D, 0,5\% Pd). A flexible grid is located at the top of the reactor to prevent fluidization of particle during the up-flow mode of operation.

The fluid circulation mode (up-flow or down-flow) is managed by 5 automatic valves located along the gas and liquid circuits and controlled simultaneously by a switch.

7 temperature probes and 6 liquid sampling valves are located along the reactor length in order to measure axial temperature and concentration profiles. One of these probes is made of three thermocouples to investigate radial temperature gradients. The other probes are of the type Pt100. Temperatures are monitored using a data acquisition system implemented in a microcomputer. Liquid samples are analyzed by a HP 5890 gas chromatograph equipped with a HP-FFAP capillary column.

Temperature control in the reactor is achieved by means of a cooling oil (Marlotherm) circulating in the jacket at a nearly constant temperature (cf. Fig. 1b).

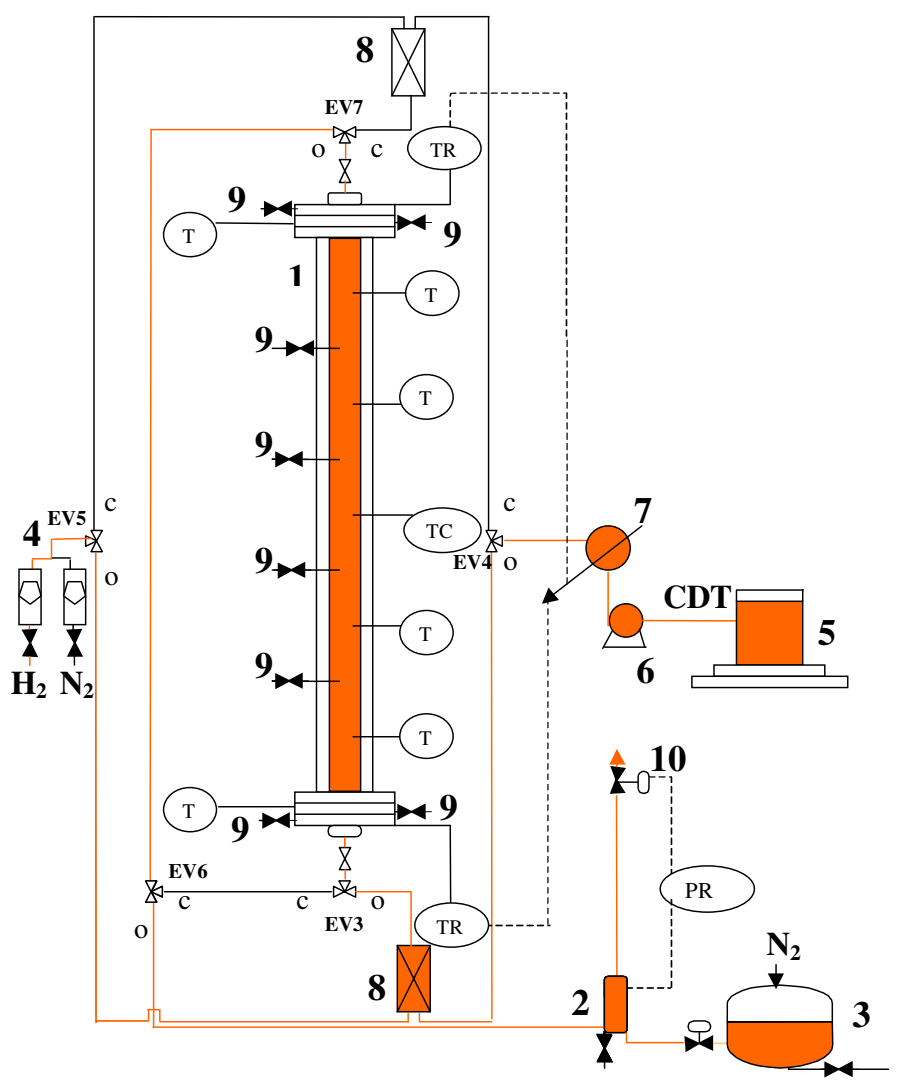

(a)

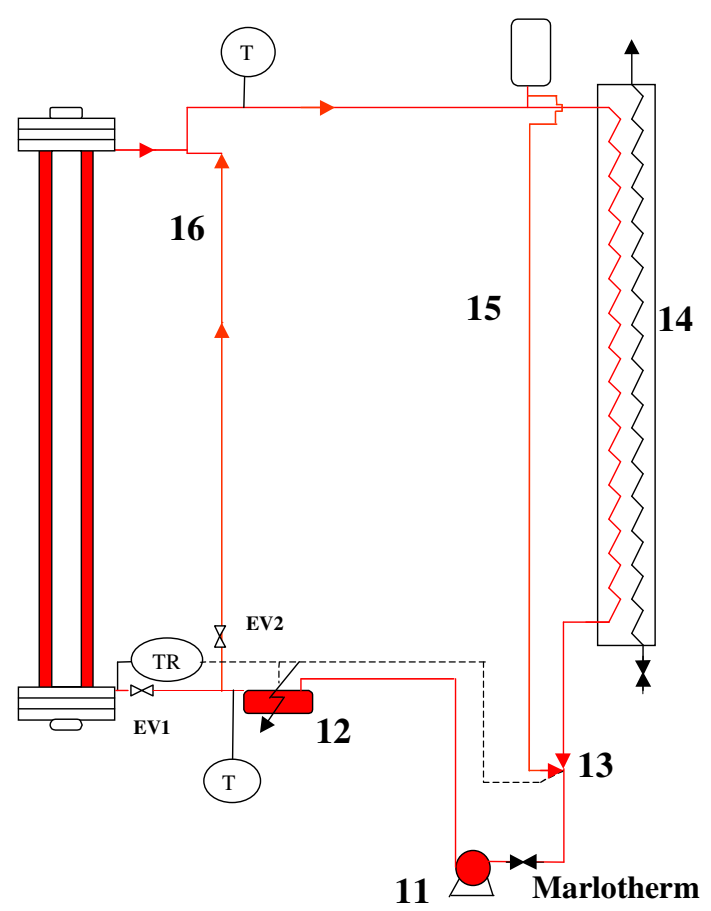

(b)

1 Jacketed packed bed column, 2 gas-liquid separator, 3 liquid storage tank, 4 gas flow meters, 5 feed tank, 6 pump, 7 pre-heater, 8 inert bed, 9 liquid sample valves, 10 pneumatic valve, 11 pump, 12 heater, 13 automatic valve, 14 heat exchanger, 15-16 by pass, EV3-EV7 automatic valves ensuring the fluid circulation way - o $=$ open, $\mathrm{c}=$ close $($ up-flow).

Fig. 1 - Experimental set-up: (a) reactant circuit (up-flow mode), (b) thermal control equipment. 


\section{RESULTS AND DISCUSSION}

\section{PRELIMINARY EXPERIMENTS}

The temperature rise observed for few preliminary experiments using pure CDT feed is shown in Fig. 2, for down flow (trickle bed) operation. It is clear from these results that the heat generated by the exothermic reaction could not be dissipated by the cooling fluid in the down-flow mode, leading to hot spots and runaway, even at atmospheric pressure and lower wall temperatures or with a diluted catalyst bed (5/6 of inert alumina pellets of the same shape). Under similar conditions, the flooded bed reactor was always found to be thermally stable.

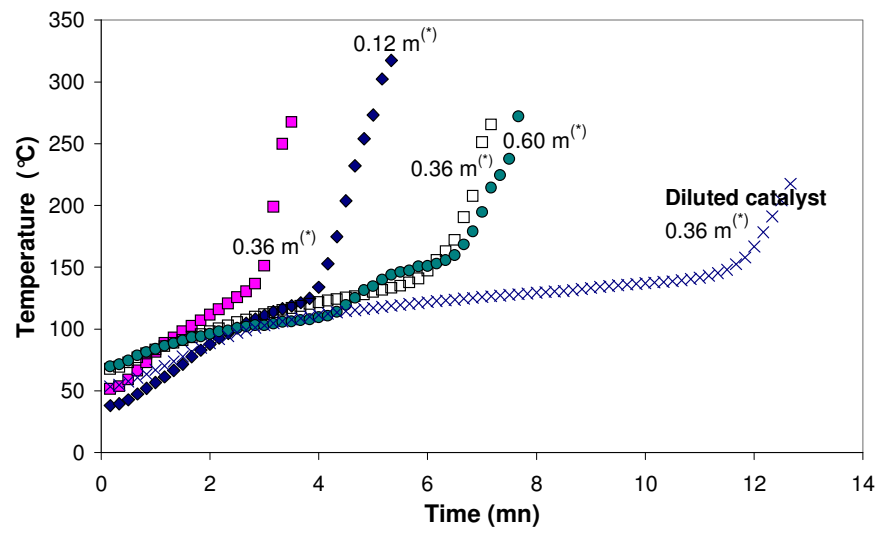

$1 \leq \mathrm{P} \leq 4$ bars

$100 \leq \mathrm{T}_{\mathrm{Me}} \leq 130^{\circ} \mathrm{C}$

$0.5 \leq \mathrm{u}_{\mathrm{Le}} \leq 1.5 \mathrm{~mm} / \mathrm{s}$

$0.04 \leq \mathrm{u}_{\mathrm{Ge}} \leq 0.15 \mathrm{~m} / \mathrm{s}$

${ }^{(*)}$ position from the inlet

Fig. 2 - Down-flow experiments with pure CDT: temperature evolution of the hot spot from the start-up of the reaction.

To enable a comparative study, a commercial solvent - isododecane (BAYER) - was used in further experiments to dilute the liquid reactant feed (15 wt. \% of CDT).

\section{EXPERIMENTAL STUDY WITH DILUTED SYSTEM (LIQUID REACTANT AND CATALYST)}

\section{Operating conditions}

Experiments were performed over a pressure range of $0.2 \mathrm{MPa}$ to $0.6 \mathrm{MPa}$ and a wall temperature between $373 \mathrm{~K}$ and $398 \mathrm{~K}$. Liquid velocity was varied from $3 \times 10^{-4}$ to $10^{-3} \mathrm{~m} / \mathrm{s}$, and gas velocity from $10^{-2}$ to $4.5 \times 10^{-2} \mathrm{~m} / \mathrm{s}$. In the flooded-bed, this corresponds to the bubble flow regime and the transition to pulse flow, according to previous investigations with nearly the same three phase system (STUBER, 1995). In the down-flow reactor, the evaluation of flow map parameters of GIANETTO and SPECCHIA (1992) suggested a trickle flow regime to prevail in the range of conditions used.

\section{Influence of operating parameters}

To investigate the influence of operating parameters (liquid velocity, temperature and pressure) on the trickle bed and flooded bed reactor performance, experimental data are presented in terms of overall hydrogen conversion and $\mathrm{CDE}$ selectivity. The overall conversion criterion was defined as follows :

$\Omega_{\mathrm{H} 2}=0.5 \mathrm{X}_{\mathrm{CDD}}+\mathrm{X}_{\mathrm{CDE}}+1.5 \mathrm{X}_{\mathrm{CDA}}$

where $\Omega_{\mathrm{H} 2}$ is defined as the ratio of the hydrogen consumption to the quantity necessary to entirely convert CDT to $\mathrm{CDE}$, and $\mathrm{X}$ is the relative molar fraction $\left(0 \leq \Omega_{\mathrm{H} 2} \leq 1.5\right)$. The selectivity of the CDE intermediate was defined as the ratio of the concentration of CDE to the sum of the concentrations of CDE and CDA. Indeed the reaction aim was to produce a maximum of $\mathrm{CDE}$, while preventing complete hydrogenation.

\section{Influence of the gas velocity}

Fig. 3 shows the variation of $\Omega_{\mathrm{H} 2}$ with gas velocity for both modes of operation. In the up-flow mode, the overall hydrogen conversion increases with the gas velocity, due to an increase in the external mass transfer coefficients - both gas-liquid and liquid-solid - as reported by STUBER et al. (1996).

In the down-flow operation, the increase in $\Omega_{\mathrm{H} 2}$ is less significant, as the external mass transfer coefficients are known to depend mostly on the liquid velocity in this flow mode (RAJASHEKARAM et al. (1998)) .

\section{Influence of the pressure}

The overall conversion was found to increase with the operating pressure (cf. Fig. 4). This can be explained by the kinetic law for the consecutive hydrogenation of CDT, showing nearly first-order with respect to hydrogen in the range of pressures studied. 
Regarding CDE selectivity, a slight negative effect of pressure was observed, as already found when studying the reaction kinetics (BENAISSA et al., 1996).

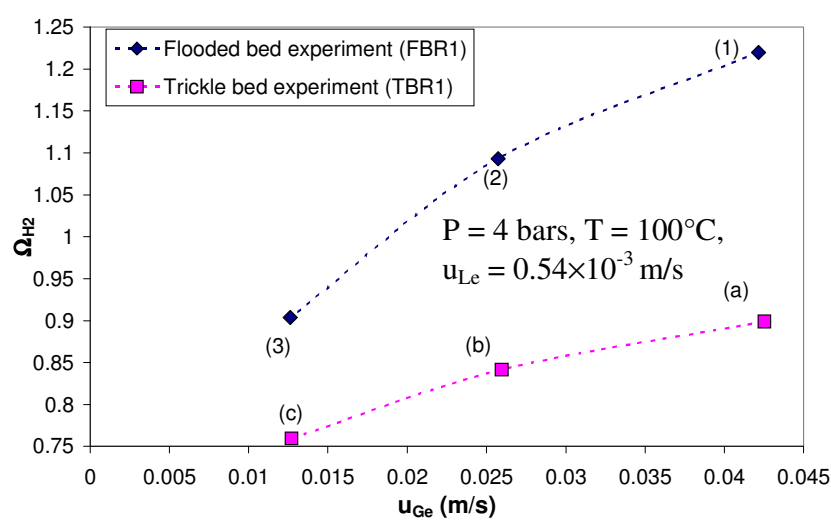

Fig. 3 - Influence of gas velocity on the overall hydrogen conversion.

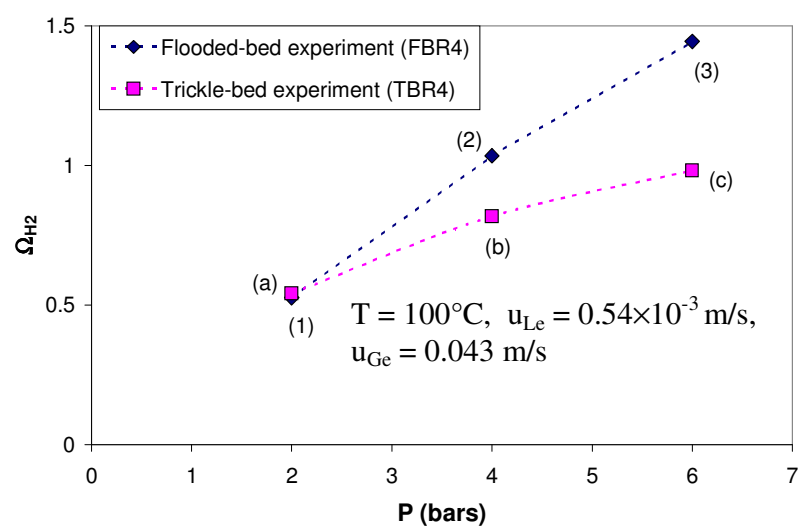

Fig. 4 - Influence of pressure on the overall hydrogen conversion.

(1), (2), (3) and (a), (b), (c) mean first, second and third run in flooded and trickle beds respectively.

Influence of the wall temperature

Wall temperature variations have only little influence on the overall conversion, whatever the flow direction was (cf. Fig. 5). A $10^{\circ} \mathrm{C}$ increase in temperature induces variations of less than $15 \%$ in $\Omega_{\mathrm{H} 2}$. This indicates the presence of significant external mass transfer limitations, which are known to depend mildly on temperature.

Influence of the liquid velocity

Fig. 6 presents results on the variation of the hydrogenation rate $\mathrm{R}_{\mathrm{H} 2}$ with a change in liquid velocity for both operating modes. The productivity was found to increase with liquid flow rate for both the reactors. This increase is more significant at lower liquid velocities, when hydrogenation is very close to completion.

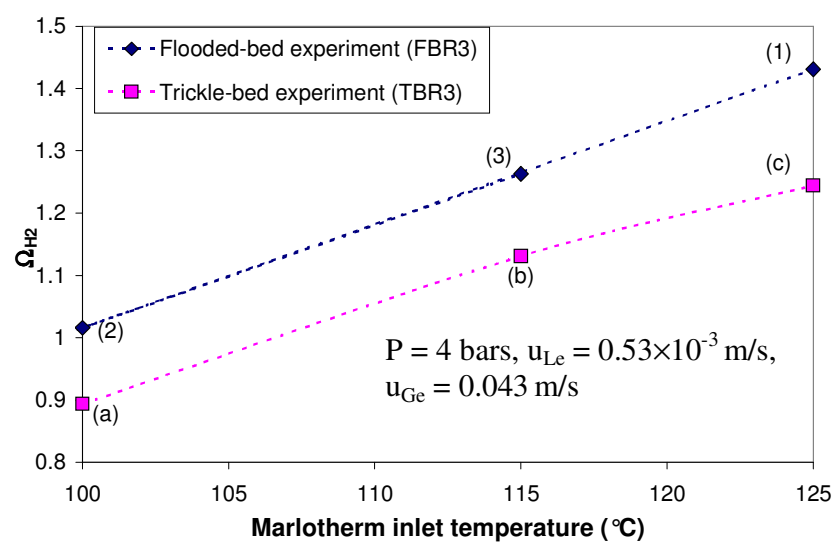

Fig. 5 - Influence of wall temperature on the overall hydrogen conversion.

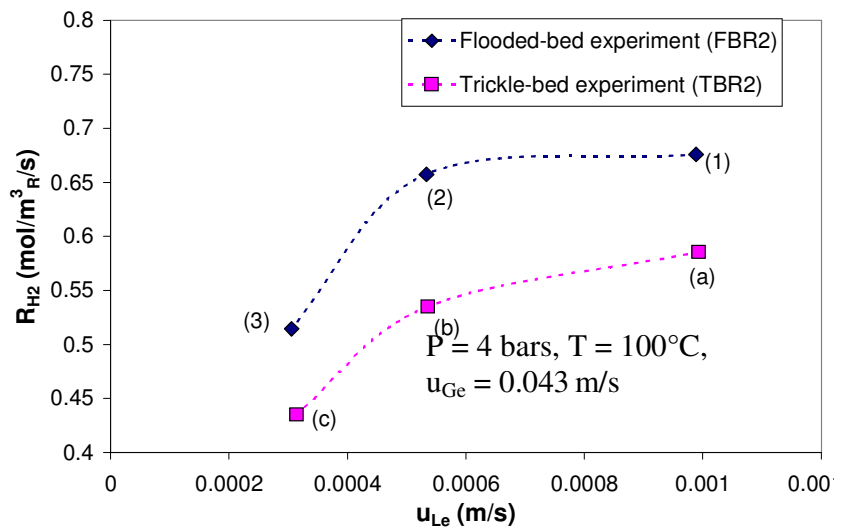

Fig. 6 - Influence of liquid velocity on the rate of hydrogenation.

\section{Comparative performances of the two modes of operation}

\section{Productivity}

Figs. 4 to 6 show that in the range of operating conditions, the hydrogenation rate is around 20\% higher in the up-flow mode, due to higher external mass transfer coefficients for the limiting reactant (hydrogen), as reported by several authors (GOTO et al., 1975).

\section{Selectivity}

In Fig. 7 the selectivity of the intermediate CDE observed in each reactor is plotted for different sets of operating conditions (excluding the measurement at 2 bars). It can be seen that the flooded-bed performance is much better than 
the trickle-bed, whatever the overall conversion was. Moreover, except the pressure, the selectivity appears to be nearly independent of operating parameters in both reactors.

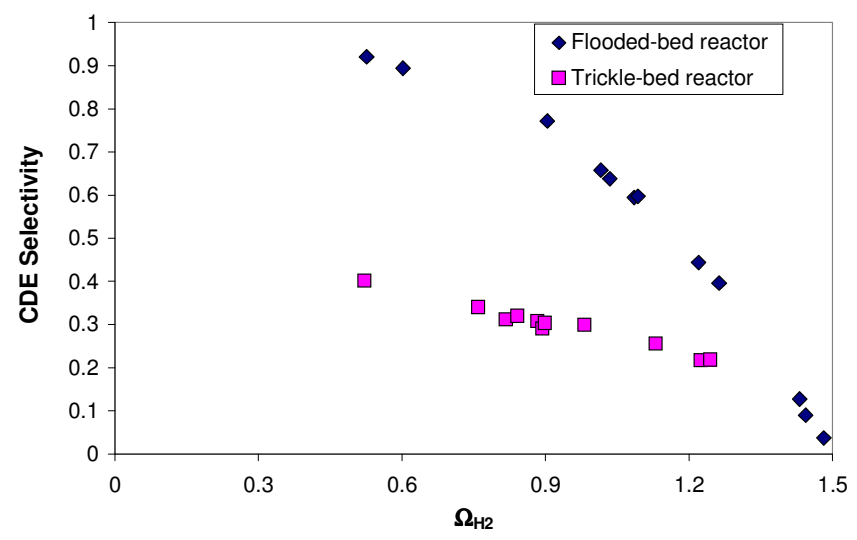

Fig. 7 - CDE selectivity in flooded and trickle bed reactors (outlet conditions).

In Fig. 13, the axial concentration profiles of intermediates in the down-flow mode are shown with a relative percentage of the CDE maximum as lower than $20 \%$, against nearly $55 \%$ in the up-flow operation.

\section{MODELING}

In order to explain the observed trends and differences, theoretical models for both reactors have been developed, based on a classical plug flow assumptions for the gas and liquid phases.

\section{FLOODED BED REACTOR}

A non-isothermal heterogeneous model was chosen to account for the external heat and mass transfer resistance and the thermal balance of the cooling fluid.

The hypotheses of the model are:

- $\quad$ radial gradients of concentration and temperature are negligible: the ratio of the reactor diameter $(0.026 \mathrm{~m})$ to the reactor length $(1.2 \mathrm{~m})$ is indeed very small, and this hypothesis has been confirmed in the up-flow mode by radial temperature measurements;

- $\quad$ plug flow is assumed for gas and liquid phases;

- the vaporization of hydrocarbons is not considered due to their low vapor pressures under the reaction conditions;

- the internal diffusion limitations for hydrogen are taken into account in an apparent kinetic law, of Eley-Rideal type;

- $\quad$ for the heat balance, gas and liquid are considered as a pseudo-homogeneous phase;

- $\quad$ the external wetting of catalyst particles is assumed to be complete.

This model led to a set of 13 combined algebraic-differential equations involving up to 21 parameters representing complex kinetics, heat and mass transfer. Parameters of the model were calculated using correlations established in the same reactor for a reaction medium similar to that used (STUBER (1995)). These sets of equations were solved by the Gear method. Details of this model and its numerical solution are described by JULCOUR (1999).

This plug flow model can suitably describe the axial concentration and temperature profiles (cf. Fig. 8 and 12), as well as the sensitivity of reactor performance to the operating parameters observed in the flooded bed reactor (as shown for instance in Fig. 9 for the gas velocity influence). The slight increasing differences between the experimental data and model predictions from measurements (1) to (3) in Fig. 9 are due to the effect of catalyst deactivation which has been neglected here. 


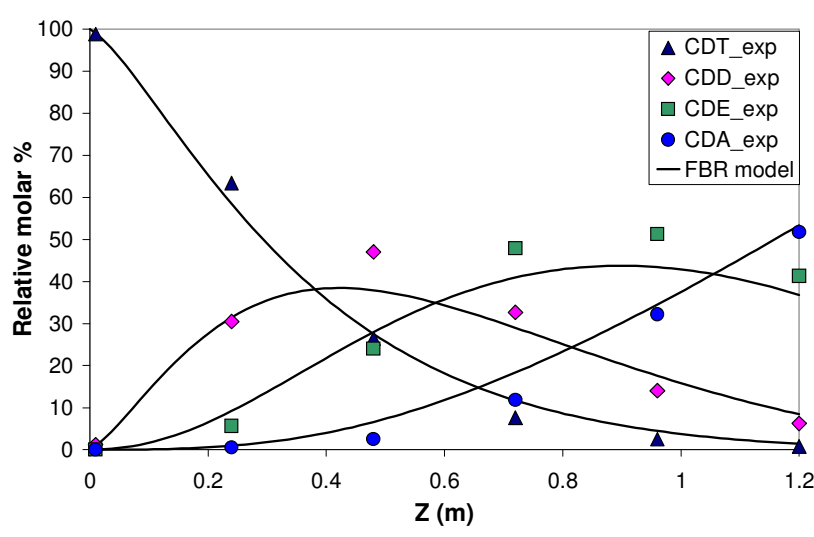

Fig. 8 -Axial concentration profiles in the flooded-bed $\left(P=4\right.$ bars, $T_{M e}=100^{\circ} \mathrm{C}$, $\left.u_{L e}=0.53 \times 10^{-3} \mathrm{~m} / \mathrm{s}, u_{G e}=0.042 \mathrm{~m} / \mathrm{s}\right)$.

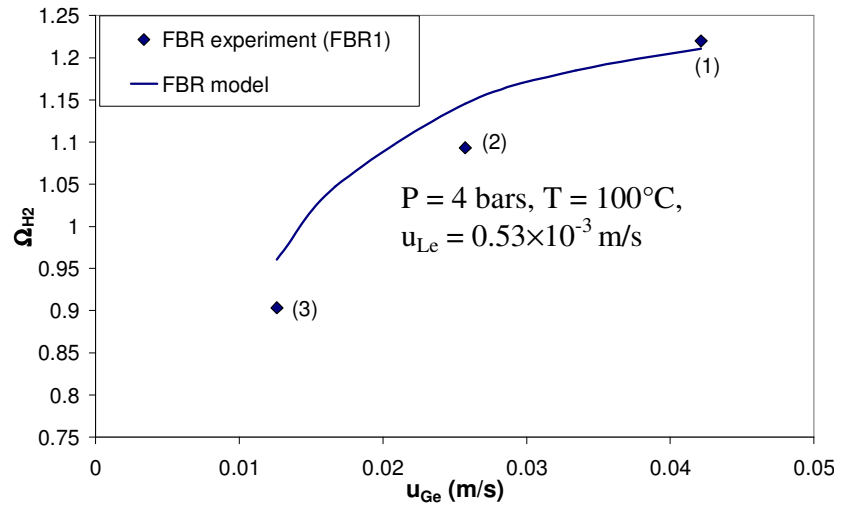

Fig. 9 - Influence of gas velocity on the overall hydrogen conversion of the flooded-bed: comparison between experimental data and model predictions.

\section{TRICKLE BED REACTOR}

A theoretical model used for the prediction of down-flow reactor performance, with various correlations from the literature to describe external mass transfer, was found to underestimate strongly the overall conversion, as can be seen in Fig. 10 (cf. appendix for the correlations used in the model). To reach the same levels of conversion, the external mass transfer coefficients of hydrogen should be at least three times higher than the actual values. One can conclude that the correlations from the literature are not suitable here. A more probable explanation is that the partial wetting of the catalyst particles is significant under these conditions, which leads to rate enhancement due to direct transfer of $\mathrm{H}_{2}$ to catalyst surface.

To simply describe this phenomenon, an overall wetting efficiency $\left(\mathrm{f}_{\mathrm{w}}\right)$, affecting all the catalyst particles in the same way, has been introduced in the plug flow model (cf. appendix). Following, for instance, the models of EL-HISNAWI et al. (1982) and RAJASHEKHARAM et al. (1998), two zones are considered at the catalyst particle surface: a wetted zone where the hydrogen transfer is limited by two consecutive resistance, and a dry zone allowing a direct access of the gaseous reactant (cf. Fig.11). At the dry zone surface, the hydrogen concentration is close to solubility, as the gassolid mass transfer resistance is very low.

The wetting efficiency was calculated by the correlation of EL-HISNAWI et al. (1982), giving a value of 0.7 . This estimation led to a good prediction of the overall conversion results (Fig. 10) and the axial temperature profile (Fig. 12), but it could not explain the poor selectivity observed (Fig. 13). This suggests the presence of a more complex segregation phenomena, as reported by VERGEL (1993) in which well irrigated parts of the bed (where the reaction is strongly limited by the hydrogen mass transfer resistance) coexists with unwetted zones where external hydrogen mass transfer limitation is reduced, accelerating the reaction rate. This leads to complete hydrogenation and hot spots formation when pure reactant feed is used.

Finally, even with a twice diluted system (catalyst and reactant), axial temperature profiles in both reactors, Fig. 12, exhibit significant differences, due to the fact that wall heat transfer coefficient being 5 times lower in the down-flow reactor than the flooded bed. After a slower increase in temperature near the reactor inlet, it further increases in the trickle bed $\left(4-5{ }^{\circ} \mathrm{C}\right)$, despite a lower overall reaction rate. Moreover, radial temperature gradients could be observed in the down-flow mode $\left(\Delta \mathrm{T}=3-4{ }^{\circ} \mathrm{C}\right.$ between the wall and the center of the reactor), while, as said previously, the temperature is uniform on any cross section of the flooded-bed. 


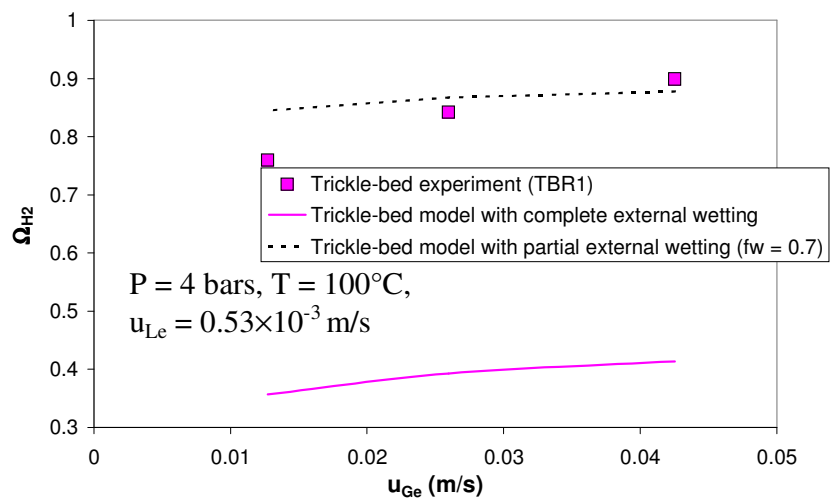

Fig. 10 - Influence of gas velocity on the overall hydrogen conversion of the trickle-bed: comparison between experimental data and model predictions.

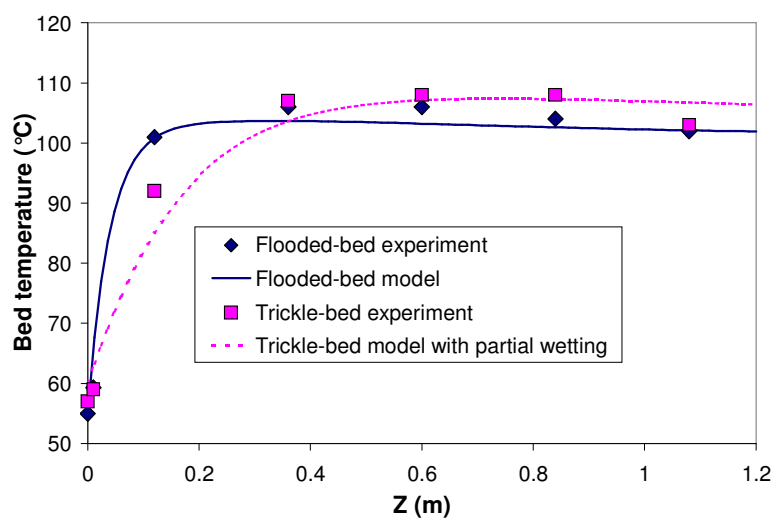

Fig. 12 - Axial temperature profiles in FBR and TBR. $\left(P=4\right.$ bars, $T_{M e}=100^{\circ} \mathrm{C}$, $u_{L e}=0.53 \times 10^{-3} \mathrm{~m} / \mathrm{s}, u_{G e}=0.043 \mathrm{~m} / \mathrm{s}$ ).

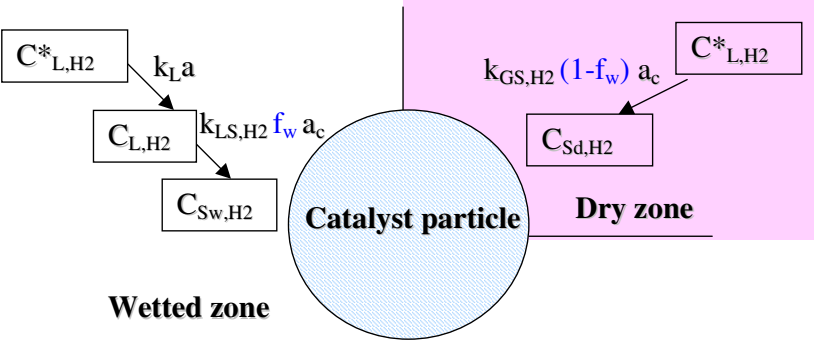

Fig. 11 - Schematic representation of hydrogen transfer at the surface of a partially wetted catalyst particle.

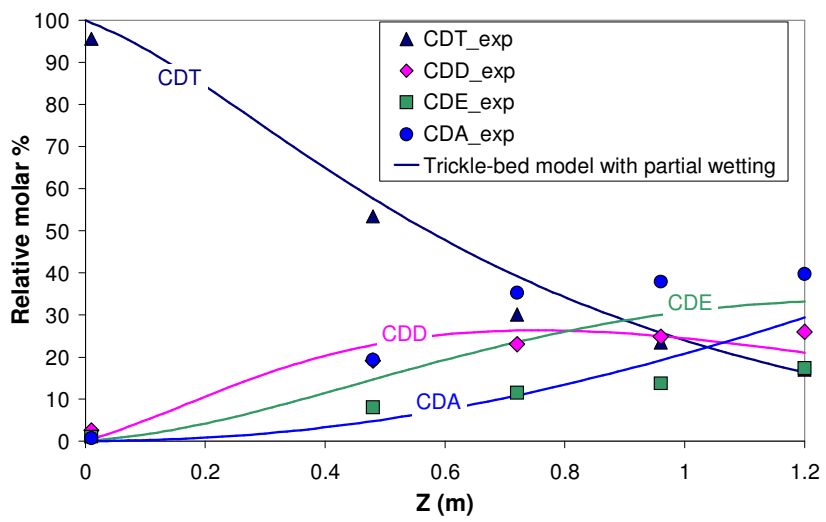

Fig. 13 - Axial concentration profiles in the trickle-bed. $\left(P=4\right.$ bars, $T_{M e}=100^{\circ} \mathrm{C}$, $u_{L e}=0.53 \times 10^{-3} \mathrm{~m} / \mathrm{s}, u_{G e}=0.043 \mathrm{~m} / \mathrm{s}$ ).

\section{CONCLUSION}

Performances of gas-liquid-solid fixed bed reactors with up-flow and down-flow operation modes have been studied and compared for an exothermic multi-step reaction with a selectivity constraint.

In this work, it is clearly shown that due to poor heat transfer in TBR, in low interaction regime, hot spots formation cannot be avoided unless the catalyst bed as well as liquid reactant feed are diluted.

The experimental study with the diluted system showed a higher productivity in the up-flow operation, with a much better selectivity for CDE.

A plug flow model, assuming complete wetting of the particles, conveniently predicted the performances of the up-flow reactor, but proved to be unsuitable for the case of the trickle-bed, underestimating the overall hydrogen conversion. A simplified model describing partial wetting of the catalyst can fit the overall conversion, but not the poor selectivity, suggesting the presence of more complex hydrodynamic heterogeneities (poorly irrigated parts of the bed). The actual behaviour of the trickle bed reactor can not be described by any simple one dimensional model.

ACKNOWLEDGMENTS: The authors wish to thank IFCPAR (Indo-French Center for the Promotion of Advanced Research) for the financial support of this work (Project no1806-1). 


\section{NOTATION}

\begin{tabular}{|c|c|c|}
\hline & $\begin{array}{l}=\text { inner wall reactor surface area, } \mathrm{m}^{2} \\
=\text { catalyst external area per reactor volume unit, } 1 / \mathrm{m} \\
=\text { concentration, mol/m } \\
=\text { hydrogen solubility concentration, } \mathrm{mol} / \mathrm{m}^{3} \\
=\text { molar flow rate per surface unit, } \mathrm{mol} / \mathrm{m}^{2} / \mathrm{s} \\
=\text { enthapy flux per surface unit, } \mathrm{W} / \mathrm{m}^{2} \\
=\text { external wetting efficiency } \\
=\text { inner wall to cooling oil heat transfer coefficient, } \\
=\text { fluid to solid heat transfer coefficient, } \mathrm{W} / \mathrm{m}^{2} / \mathrm{K} \\
=\text { bed to wall heat transfer coefficient, } \mathrm{W} / \mathrm{m}^{2} / \mathrm{K} \\
=\text { gas-solid mass transfer coefficient, } \mathrm{m} / \mathrm{s} \\
=\text { gas-liquid volumetric mass transfer coefficient, } 1 / \mathrm{s}\end{array}$ & 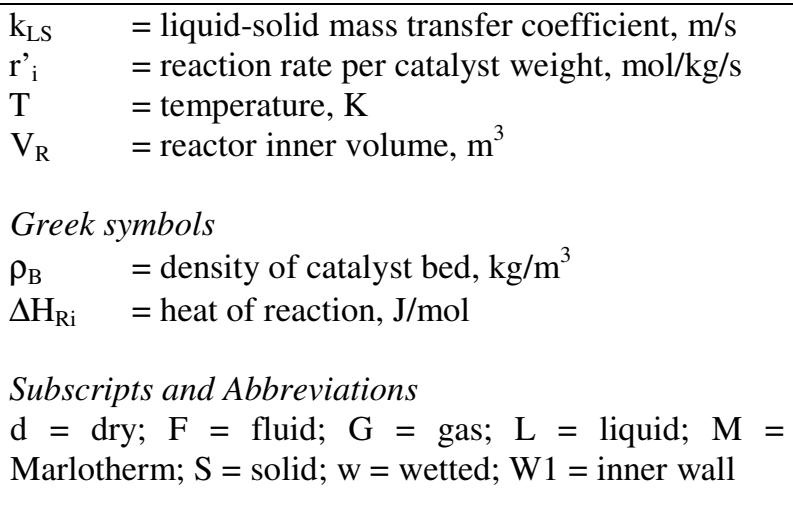 \\
\hline
\end{tabular}

\section{REFERENCES}

Benaissa M., Carillo Le Roux G., Joulia X., Chaudhari R.V., Delmas H., 1996, Kinetic modeling of 1,5,9cyclododecatriene on $\mathrm{Pd} / \mathrm{Al}_{2} \mathrm{O}_{3}$ catalyst including isomerization. Ind. Eng. Chem. Res. 35, 2091-2095.

Dwidedi, P. N. and Upadhyay, S. N., 1977, Particle-fluid mass transfer in fixed and fluidized beds. Ind. Eng. Chem. Process. Des. Dev. 16 (2), 157-165.

El-Hisnawi, A. A., Dudukovic, M. P. and Mills, P. L., 1982, Trickle - bed reactors: dynamic tracer tests, reaction studies, and modeling of reactor performance. ACS Symp. Ser. 196, 421-440.

Fukushima, S. and Kusaka, K., 1977, Liquid-phase volumetric and mass-transfer coefficient, and boundary of hydrodynamic flow region in packed column with cocurrent downward flow. J.Chem. Eng. Japan 10 (6), 468-474.

Gianetto, A. and Specchia, V., 1992, Trickle - bed reactor: state of art and perspectives. Chem. Eng. Sci. 47 (13-14), 3197-3213.

Goto, S., Levec, J. and Smith, J. M., 1975, Mass transfer in packed beds with two-phase flow. Ind. Eng. Chem. Process. Des. Dev. 14 (4), 473-478.

Goto, S. and Mabuchi, K., 1984, Oxidation of ethanol in gas - liquid cocurrent upflow and downflow reactors. Can. J. Chem. Eng. 62, 865-869.

Goto, S., Chatani, T. and Matouq, M. H., 1993, Hydration of 2-methyl-2-butene in gas - liquid cocurrent upflow and downflow reactors. Can. J. Chem. Eng. 71, 821-823.

Julcour, C., 1999, Réacteur catalytique à lit fixe et co-courant ascendant: modélisation dynamique, sélectivité et comparaison avec le co-courant descendant. Thèse de Doctorat de l'INP Toulouse.

Khadilkar, M. R., Wu, Y. X., Al-Dahhan, M. H., Dudukovic, M. P. and Colakyan ,M., 1996, Comparison of trickle-bed and upflow reactor performance at high pressure: model predictions and experimental observations. Chem. Eng. Sci. 51 (10), 2139-2148.

Larachi, F., Laurent, A., Wild, G. and Midoux, N., 1991, Some experimental liquid saturation results in fixed - bed reactors operated under elevated pressure in cocurrent upflow and downflow of the gas and the liquid. Ind. Eng. Chem. Res. 30, 2404-2410.

Mills, P. L., Beaudry, E. G. and Dudukovic, M. P., 1984, Comparison and prediction of reactor performance for packed beds with two - phase flow: downflow, upflow and countercurrent flow. I. Chem. E. Symp. Ser. 87, 527-534.

Rajashekharam, M. V., Jaganathan, R. and Chaudhari, R. V., 1998, A trickle-bed reactor model for hydrogenation of 2,4 dinitrotoluene: experimental verification. Chem. Eng. Sci. 53 (4), 787-805.

Satterfield, C. N., Van Eek, M. W. and Bliss, G. S., 1978, Liquid-solid mass transfer in packed beds with downward concurrent gas-liquid flow. AIChE J. 24 (4), 709-718.

Specchia V. and Baldi, G., 1979, Heat transfer in trickle-bed reactors. Chem. Eng. Commun. 3, 483-499.

Stüber, F., 1995, Sélectivité en réacteur catalytique triphasique : analyse expérimentale et théorique d'hydrogénations consécutives en lit fixe catalytique à co-courant ascendant de gaz et de liquide. Thèse de Doctorat de l'INP Toulouse.

Stüber, F., Wilhelm, A. M. and Delmas, H., 1996, Modelling of three phase catalytic upflow reactor: a significant chemical determination of liquid-solid and gas-liquid mass transfer coefficients. Chem. Eng. Sci. 51 (10), 2161-2167.

Tan, C. S. and Smith, J. M., 1982, A dynamic method for liquid-particle mass transfer in trickle beds. AIChE J. 28 (2), 190-195.

Vergel Hernandez, C. A., 1993, Les réacteurs à lit fixe avec écoulement de gaz et de liquide. Comparaison sur le plan théorique et expérimental de la performance du réacteur dans différents sens d'écoulement. Thèse de Doctorat de l'INP Lorraine.

Whitaker, S., 1972, Forced convection heat transfer correlations for fluid in pipes, past flat plates, single cylinders, simple spheres, and for fluid in packed beds and tube bundles. AIChE J. 18 (2), 361-371. 


\section{APPENDIX : TRICKLE-BED MODEL WITH PARTIAL WETTING}

\section{Mass balances}

- Liquid phase (plug flow)

$>$ Hydrocarbons $(\mathrm{k})$

$$
\begin{aligned}
& 0=-\frac{\partial \mathrm{F}_{\mathrm{L}, \mathrm{k}}}{\partial \mathrm{z}}-\mathrm{f}_{\mathrm{w}} \mathrm{a}_{\mathrm{c}}\left(\mathrm{k}_{\mathrm{LS}}\right)_{\mathrm{k}}\left(\mathrm{C}_{\mathrm{L}, \mathrm{k}}-\mathrm{C}_{\mathrm{S}, \mathrm{k}}\right) \\
& \mathrm{k}=\mathrm{CDT}, \mathrm{CDD}, \mathrm{CDE}, \mathrm{CDA} \\
& >\mathrm{H}_{2} \\
& 0=-\frac{\partial \mathrm{F}_{\mathrm{L}, \mathrm{H} 2}}{\partial \mathrm{z}}-\mathrm{f}_{\mathrm{w}} \mathrm{a}_{\mathrm{c}}\left(\mathrm{k}_{\mathrm{LS}}\right)_{\mathrm{H} 2}\left(\mathrm{C}_{\mathrm{L}, \mathrm{H} 2}-\mathrm{C}_{\mathrm{Sw}, \mathrm{H} 2}\right)+\mathrm{k}_{\mathrm{L}} \mathrm{a}\left(\mathrm{C}_{\mathrm{L}, \mathrm{H} 2}^{*}-\mathrm{C}_{\mathrm{L}, \mathrm{H} 2}\right)
\end{aligned}
$$

- $\quad$ Catalytic phase

$$
\begin{aligned}
& >\text { Hydrocarbons }(\mathrm{k}) \\
& 0=\mathrm{f}_{\mathrm{w}} \mathrm{a}_{\mathrm{c}}\left(\mathrm{k}_{\mathrm{LS}}\right)_{\mathrm{k}}\left(\mathrm{C}_{\mathrm{L}, \mathrm{k}}-\mathrm{C}_{\mathrm{S}, \mathrm{k}}\right)+\rho_{\mathrm{B}} \sum_{\mathrm{i}} v_{\mathrm{ik}}\left(\mathrm{f}_{\mathrm{w}} \mathrm{r}_{\mathrm{i}, \mathrm{w}}\left(\mathrm{C}_{\mathrm{S}, \mathrm{k}}, \mathrm{C}_{\mathrm{Sw}, \mathrm{H} 2}, \mathrm{~T}_{\mathrm{S}}\right)+\left(1-\mathrm{f}_{\mathrm{w}}\right) \mathrm{r}_{\mathrm{i}, \mathrm{d}}\left(\mathrm{C}_{\mathrm{S}, \mathrm{k}}, \mathrm{C}_{\mathrm{Sd}, \mathrm{H} 2}, \mathrm{~T}_{\mathrm{S}}\right)\right) \\
& \mathrm{k}=\mathrm{CDT}, \mathrm{CDD}, \mathrm{CDE}, \mathrm{CDA} \\
& >\mathrm{H}_{2} \\
& 0=\mathrm{f}_{\mathrm{w}} \mathrm{a}_{\mathrm{c}}\left(\mathrm{k}_{\mathrm{LS}}\right)_{\mathrm{H} 2}\left(\mathrm{C}_{\mathrm{L}, \mathrm{H} 2}-\mathrm{C}_{\mathrm{Sw}, \mathrm{H} 2}\right)+\rho_{\mathrm{B}} \sum_{\mathrm{i}} v_{\mathrm{iH} 2}\left(\mathrm{f}_{\mathrm{w}} \mathrm{r}_{\mathrm{i}, \mathrm{w}}^{\prime}\left(\mathrm{C}_{\mathrm{S}, \mathrm{k}}, \mathrm{C}_{\mathrm{Sw}, \mathrm{H} 2}, \mathrm{~T}_{\mathrm{S}}\right)\right) \\
& 0=\left(1-\mathrm{f}_{\mathrm{w}}\right) \mathrm{a}_{\mathrm{c}}\left(\mathrm{k}_{\mathrm{GS}}\right)_{\mathrm{H} 2}\left(\mathrm{C}_{\mathrm{L}, \mathrm{H} 2}^{*}-\mathrm{C}_{\mathrm{S} \mathrm{H}, \mathrm{H} 2}\right)+\rho_{\mathrm{B}} \sum_{\mathrm{i}} v_{\mathrm{iH} 2}\left(\left(1-\mathrm{f}_{\mathrm{w}}\right) \mathrm{r}_{\mathrm{i}, \mathrm{d}}\left(\mathrm{C}_{\mathrm{S}, \mathrm{k}}, \mathrm{C}_{\mathrm{S} \mathrm{H}, \mathrm{H} 2}, \mathrm{~T}_{\mathrm{S}}\right)\right)
\end{aligned}
$$

\section{Energy balances}

- $\quad$ Fluid phase (gas + liquid)

$0=-\frac{\partial\left((\mathrm{Fh})_{\mathrm{F}}\right)}{\partial \mathrm{z}}+\mathrm{a}_{\mathrm{c}} \mathrm{h}_{\mathrm{FS}}\left(\mathrm{T}_{\mathrm{S}}-\mathrm{T}_{\mathrm{F}}\right)-\frac{\mathrm{h}_{\mathrm{w}} \mathrm{A}_{1}}{\mathrm{~V}_{\mathrm{R}}}\left(\mathrm{T}_{\mathrm{F}}-\mathrm{T}_{\mathrm{W} 1}\right)$

- Catalyst phase

$0=-\mathrm{a}_{\mathrm{c}} \mathrm{h}_{\mathrm{FS}}\left(\mathrm{T}_{\mathrm{S}}-\mathrm{T}_{\mathrm{F}}\right)-\rho_{\mathrm{B}} \sum_{\mathrm{i}} \Delta \mathrm{H}_{\mathrm{Ri}}\left(\mathrm{f}_{\mathrm{w}} \mathrm{r}_{\mathrm{i}, \mathrm{w}}+\left(1-\mathrm{f}_{\mathrm{w}}\right) \mathrm{r}^{\prime}{ }_{\mathrm{i}, \mathrm{d}}\right)$

- Cooling oil (Marlotherm)

$0=-\frac{\partial}{\partial \mathrm{z}}\left((\mathrm{Fh})_{\mathrm{M}}\right)+\frac{\mathrm{h}_{2} \mathrm{~A}_{1}}{\mathrm{~V}_{\mathrm{an}}}\left(\mathrm{T}_{\mathrm{W} 1}-\mathrm{T}_{\mathrm{M}}\right) \quad\left(0=\mathrm{h}_{\mathrm{w}} \mathrm{A}_{1}\left(\mathrm{~T}_{\mathrm{F}}-\mathrm{T}_{\mathrm{W} 1}\right)-\mathrm{h}_{2} \mathrm{~A}_{1}\left(\mathrm{~T}_{\mathrm{W} 1}-\mathrm{T}_{\mathrm{M}}\right)\right)$

\section{Correlations used in the trickle-bed model}

Liquid holdup

External wetting factor $f_{w}$

Coefficient $\mathrm{k}_{\mathrm{L}} \mathrm{a}$

Coefficient $\mathrm{k}_{\mathrm{LS}}$ for $\mathrm{H}_{2}$

Coefficient $\mathrm{k}_{\mathrm{LS}}$ for hydrocarbons

Coefficient $\mathrm{k}_{\mathrm{GS}}$

Coefficient $h_{\mathrm{FS}}$

$$
h_{F S}=f_{w} \times h_{L S}+\left(1-f_{w}\right) \times h_{G S}
$$

Coefficient $h_{w}$
LARACHI et al. (1991)

EL-HISNAWI et al. (1982)

FUKUSHIMA and KUSAKA (1977)

TAN and SMITH (1982)

SATTERFIELD et al. (1978)

DWIDEDI and UPADHYAY (1997)

WHITAKER (1972)

SPECCHIA and BALDI (1979) 